Received:

$12-X-2021$

Accepted:

20-1-2022

Published Online:

4-II-2022

\section{Exfoliative Cheilitis More than an Aesthetic Problem: Case Report}

\section{Queilitis exfoliativa más que un problema estético: reporte de casos}

Yadira V. Boza-Oreamuno DDS, MSc¹; Andrés Mena-Lizano²

1. Department of Diagnostic and Surgical Sciences, Faculty of Dentistry, University of Costa Rica, San José, Costa Rica. https://orcid.org/0000-0002-0367-8664

2. Fifth year student, Faculty of Dentistry, University of Costa Rica, San José, Costa Rica.

https://orcid.org/0000-0001-7529-4507

Correspondence to: Yadira V. Boza Oreamuno - yadira.boza@ucr.ac.cr

ABSTRACT: Exfoliative cheilitis (EC) is a rare and chronic inflammatory condition. It is characterized by a continuous peeling of the vermilion of the lips and abnormal production of keratin scales. Treatment is difficult due to its chronic nature and it is often refractory. The objective of this article is to describe the management of EC and its impact on quality of life through two clinical cases. Two patients with EC are reported: one 21 years old with allergic rhinitis and gastric reflux, the other 18 years old, with a history of anxiety symptoms, without medication or psychiatric control. They had chronic scaly and crusty areas on both lip vermilions. In one of the patients, a biopsy was prescribed and he was treated with antifungals and topical vitamin $\mathrm{E}$. Both patients were prescribed hydration, balanced diet, the application of moisturizing lip balm with sunscreen and modification of parafunctional habits, behavioral aid. The treatment healed the condition and eased their daily life and improved personal perception. Nibbling and lip licking favor dryness and superinfection in patients with EC; for its part, hydration, topical vitamin E and behavioral aid, improved this condition.

KEY WORDS: Exfoliative cheilitis; Lips; Desquamation; Biopsy; Treatment.

RESUMEN: La queilitis exfoliativa (QE) es una afección inflamatoria crónica y poco común. Se caracteriza por una descamación continua del bermellón de los labios y producción anormal de escamas de queratina. El tratamiento es difícil debido a su naturaleza crónica y suele ser refractaria. El objetivo de este artículo es describir por medio de dos casos clínicos el manejo de la QE y su impacto en la calidad de vida. Se informa de dos pacientes con $Q E$, uno de 21 con rinitis alérgica y reflujo gástrico, el otro de 18 años, con antecedente de cuadros de ansiedad, sin medicación ni control psiquiátrico. Presentaban áreas descamadas y costrosas en ambos bermellones labiales de forma crónica y sin resolución. En un caso se realizó biopsia y fue tratado 
con antifúngicos y vitamina E tópica. En ambos pacientes se insistió en la hidratación, alimentación balanceada, uso de bálsamo labial humectante con protector solar y modificación de hábitos parafuncionales, ayuda conductual logrando una resolución que facilitaba sus labores cotidianas y mejorando la percepción personal. El mordisqueo y lamer los labios favorecen la resequedad y sobreinfección en pacientes con QE; por su parte, la hidratación, la vitamina E tópica y la ayuda conductual favorecen en mejorar esta condición.

PALABRAS CLAVE: Queilitis exfoliativa; Labios; Descamación; Biopsia; Tratamiento.

\section{INTRODUCTION}

The lips are an essential component of the symmetry and aesthetics of the face, they consist of two parts, the upper and lower lips intersect at the mouth angle, referred to as the commissure (1). The lip is made up of mucosa on the inside and a muscular area covered by skin on the outside called vermilion (2), it is what we more commonly known as the lip proper.

The vermilion of the lips is exposed to numerous external agents which can cause damage, such as dry weather (with high or low temperatures), wind and exposure to ultraviolet rays (3), as well as toothpaste, cosmetics and topical treatments (4); causing desquamation, erosion, crusting, fissuring (5) and even precancerous lesions or cancer (6).

Exfoliative cheilitis (EC) is a rare and chronic inflammatory dermatological condition (7). It is characterized by a continuous peeling of the vermilion of the lips and abnormal production of keratin scales (8). It is associated with stress and anxiety, as well as parafunctional activities including lip licking or biting (9). It is refractory to treatment, including treatment with corticosteroids, antibiotics, antifungals and immunosuppressants (10).

The objective of this work is to describe the clinical characteristics and management of EC in two young patients and its impact on their quality of life.

\section{CASE REPORT}

\section{CASE 1}

A 21-year-old male patient, single, electrical engineering student. He complains: "I have my vermilion with scaly areas". On direct questioning, he reported a history of allergic rhinitis and gastric reflux. He does not smoke or drink alcoholic beverages. For the lips, he has used Calendula lip balms of various brands, vitamin B5 or hyaluronic acid gels, but it did not heal and in fact worsened, improving only when he took Vitamin E $300 \mathrm{IU}$ a day and used Dermosupril $0.1 \%$ cream (Desonide; Megalabs Chile S.A). He explained that this situation affects his life, he dislikes his appearance and feels uncomfortable when interacting since people continually stare at his lips.

When conducting the clinical examination, Fordyce granules were observed in the upper vermilion and in both yugal mucosa; back of tongue coated and both lip vermilions covered by thick, adherent, whitish-white scales, some of them large, but when removing them, normal-appearing epithelium of the lip is evidenced (Figure 1), the patient reports that since childhood he sucked his lips and when he was a teenager he would "tear off" his "little skins", it is cyclical, sometimes remaining raw, but he no longer does it. No palpable lymph nodes were found at the neck level. No facial or skin contour alterations were observed. 

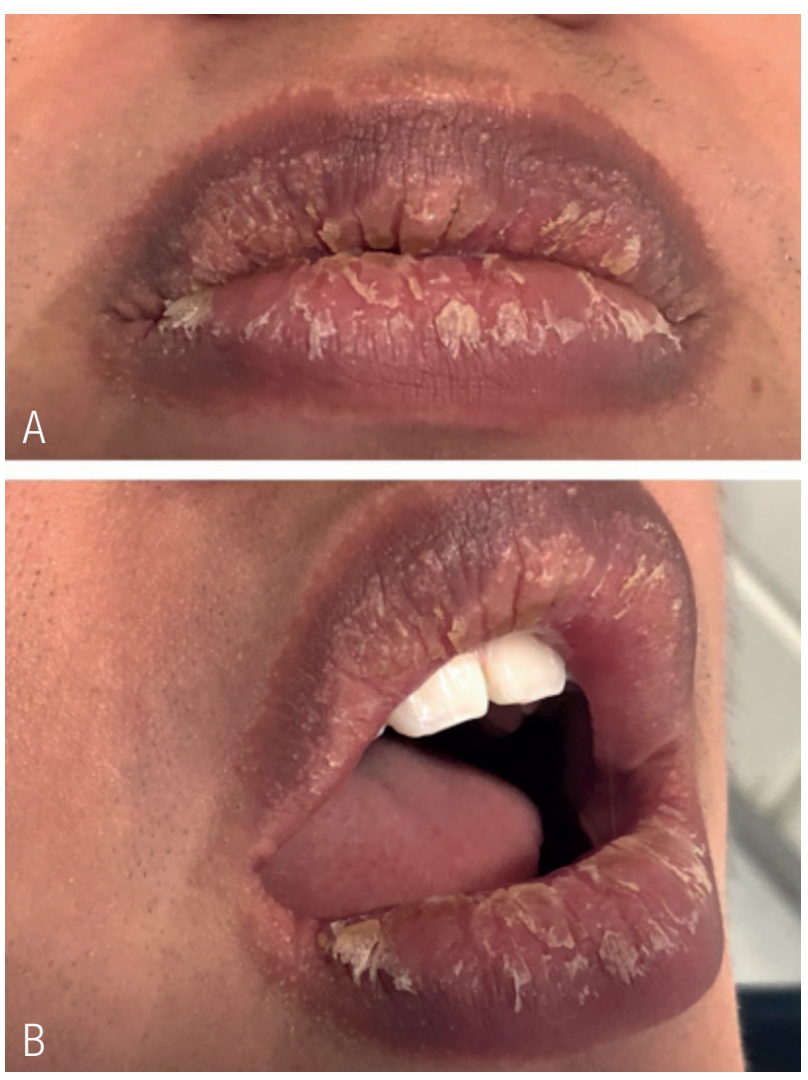

Figure 1. Vermilion covered by thick, adherent yellowish-white scales, some of which are large, but when detached, normalappearing tissue of the lip is evidenced.

He is consulted and reports that he suffers constipation and that his hydration is poor, although he has lately been drinking flavored water without sugar. Laboratory tests were prescribed: complete blood count, clotting times, serum levels of vitamin B12, folic acid, iron, ferritin and IgE; being hemoglobin 13.8 (14-18) g/dL, hematocrit 40.1\% (42-52) and the other results within the norm.

Under the clinical diagnosis of EC, an incisional biopsy was performed in the lower vermilion to the right of the midline with $2 \%$ infiltrative anesthesia, an oval incision was made following the lines of the lip, it was deepened $4 \mathrm{~mm}$, the specimen was sent for study histopathological in 10\% formalin, hemostasis was performed and sutured with 6/0 catgut (Figure 2.A). Recommendations were given to the patient to carry out adequate oral hygiene, Enantyum $® 25 \mathrm{mg}$ (Dexketoprofen trometamol;
Menarini Group, Spain) was prescribed, one tablet

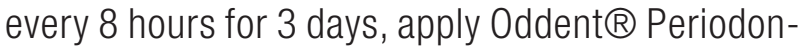
tal gel (chlorhexidine digluconate 0.20\%; Menarini Group, Spain) on the surface 3 times a day, for 5 days. At the 8-day control, he shows very significant healing of the area (Figure 2.B).

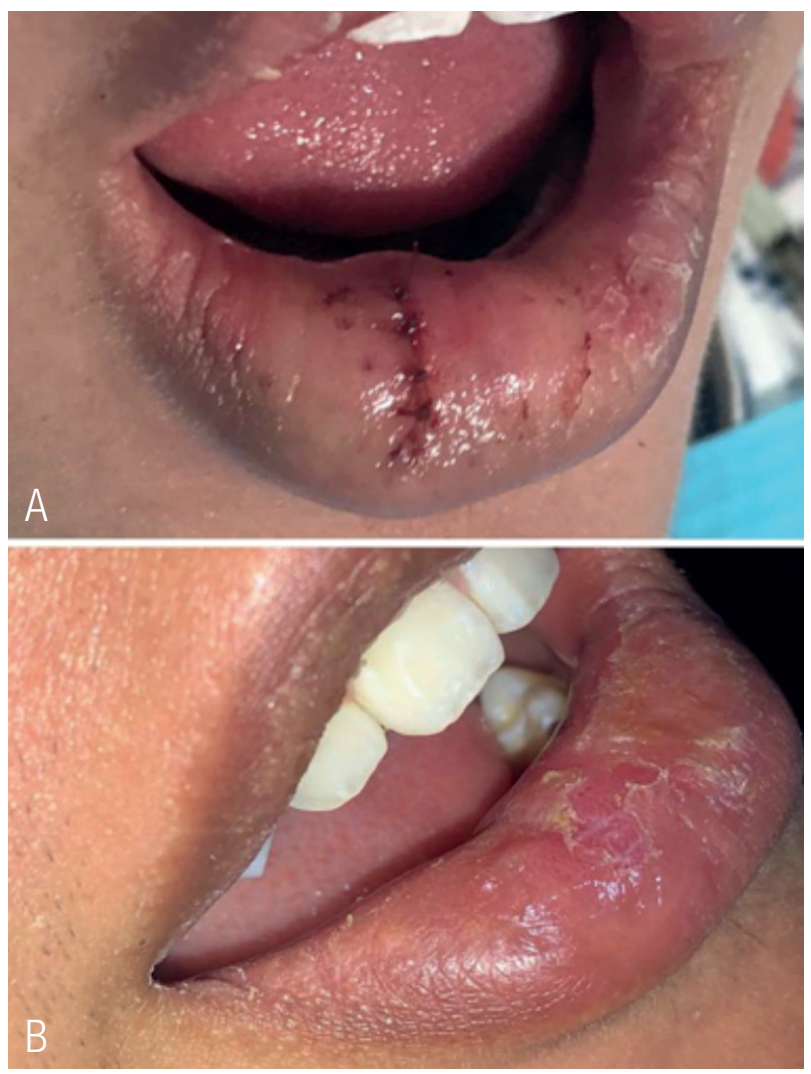

Figure 2. A. Biopsy of the lesion. B. Clinical control at eight days, with good wound healing, rest of the vermilion dry and with scaly areas.

The histopathological study showed epithelium with hyperplasia, papillomatosis and hyperkeratosis of the parakeratoysis type, without atypia, at the superficial level hyphae and yeasts were identified, as well as bacterial superinfection with exocytosis of some neutrophils (Figure 3). EC diagnosis and superficial mycosis.

The condition is explained to the patient, treatment with Diflucan 150mg (Fluconazol; Pfizer PGM, France) is prescribed once a day for 10 
days. In addition, to keeping a balanced diet and hydration, it is recommended to use a moisturizing lip balm with sun protection factor (SPF) daily on demand, the patient felt comfortable with Labello Hydro Care SPF 15 (Natural oils; BDF México S.A.), in addition to using a vitamin $\mathrm{E}$ capsule every 8 hours applying a little of that oil instead of the balm. Avoid licking your lips and pulling peeling; the patient is advised to manage stress, it is recommended to receive therapy, or to engage in some recreational activity for relaxation.

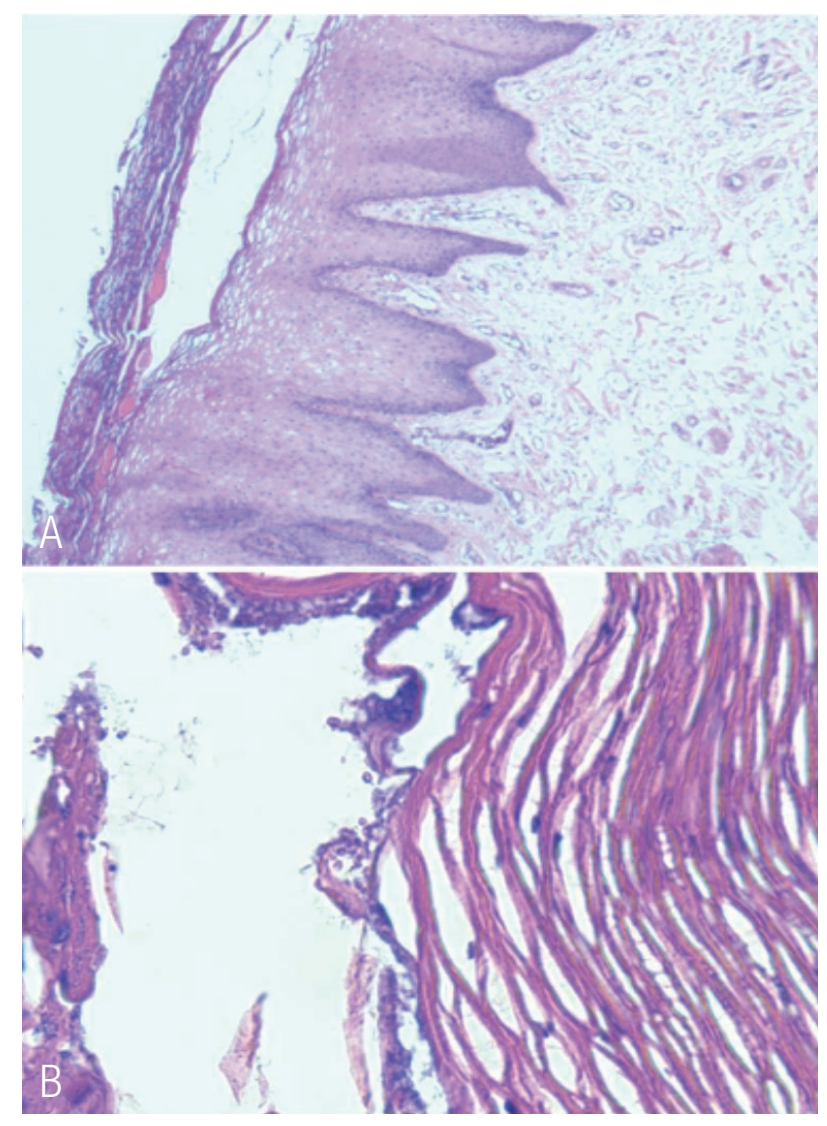

Figure 3. A. Epithelial hyperplasia, without atypia, papillomatosis and hyperkeratosis (H\&E, 20X). B. Parakeratosis, hyphae and yeasts were identified at superficial level (H\&E, 40X).

He has been followed up and after three months vermilion, moisturizing has improved (Figure 4), he reports feeling good, has managed stress and has followed recommendations; only the application of vitamin E every 8 hours has not met the schedule, using lip balm is more practical.
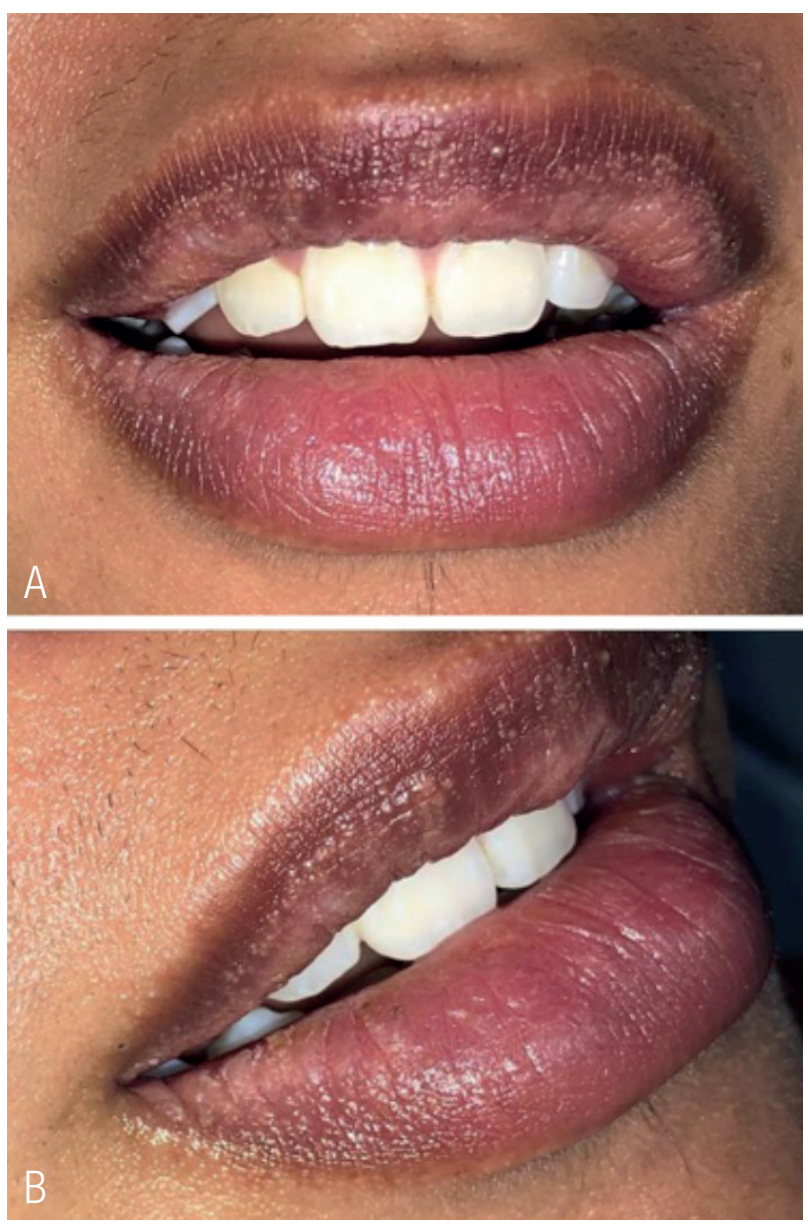

Figure 4. After 3 months, both vermilions are moisturized and show reduced scaly areas.

\section{CASE 2}

A 18-year-old male single, systems engineering student. He complains that he has scaly areas in his lips. In the direct questioning, he did not report a systemic or allergic history, he indicated that he had symptoms of anxiety, however he did not take any type of medication or was under psychiatric control. He does not smoke or drink alcoholic beverages.

When conducting the clinical examination, a dry lower lip vermilion was observed with scaly 
areas, a line that divides the vermilion and the resected upper labial mucosa at the midline level (Figure 5). Both lips and tends to tear it off with his teeth especially when stressed, also because it looks unpleasant and bothers him when he speaks, sometimes it even breaks and hurts when opening his mouth or eating. The perioral skin is dry, with slight scaling and some erythematous areas. No palpable lymph nodes were found at the neck level.
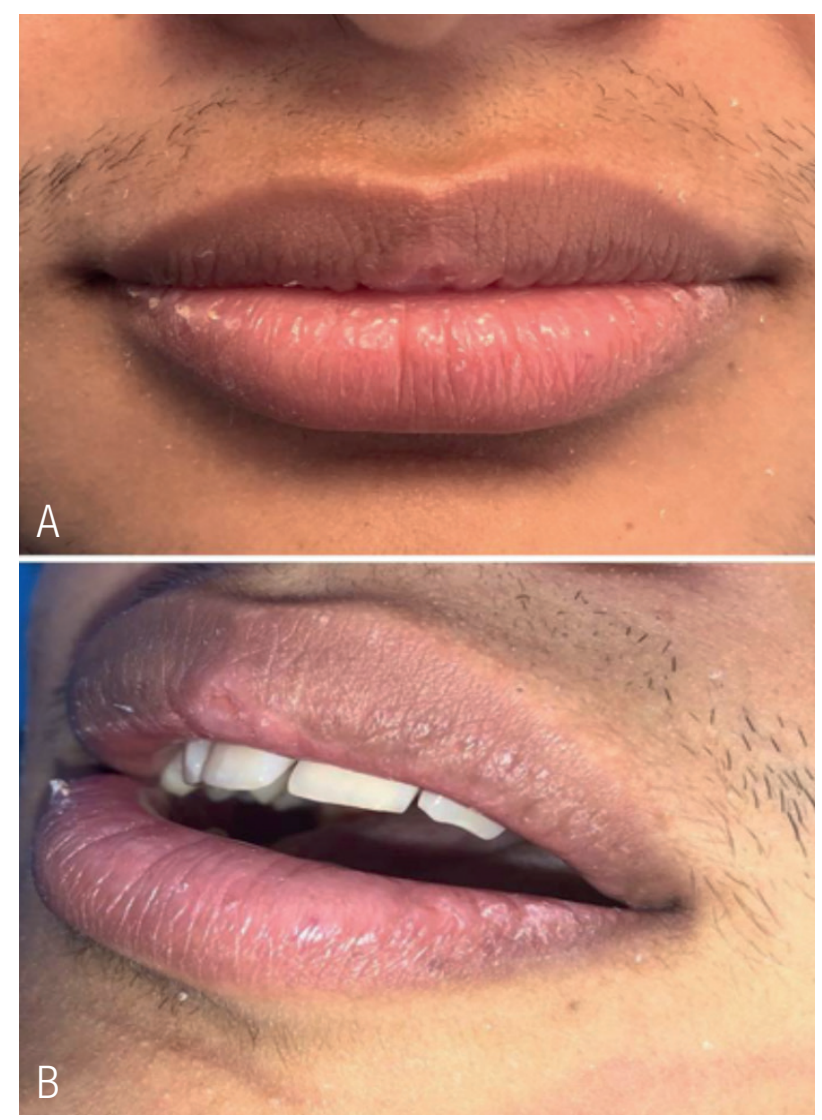

Figure 5. A. Dry, fissured lower vermilion with scaly areas. B. Superior vermilion with coastline at the level of the midline and rest of the dividing line with dry and tight labial mucosa.

Under the clinical diagnosis of EC, the patient is explained of his condition. He is asked and he confirms that his consumption of water is minimal, he prefers soft drinks, he is recommended to hydrate properly by consuming enough water and at topical level, to use a lip balm with SPF daily on demand, the patient felt comfortable with the Tropical SPF Lip Balm 30 (Hawaiian Tropic ${ }^{\text {TM }}$; USA), he is instructed to avoid licking his lips and picking off flakes. In addition, it is emphasized that the condition can be aggravated by stress or anxiety episodes; he is also advised to seek treatment for this condition.

The follow up after a month and a half, shows a noticeable improvement (Figure 6), both visually and to the touch of the vermilion on both lips, he has opted for a behavioral therapy that has helped him in managing depression and anxiety episodes.
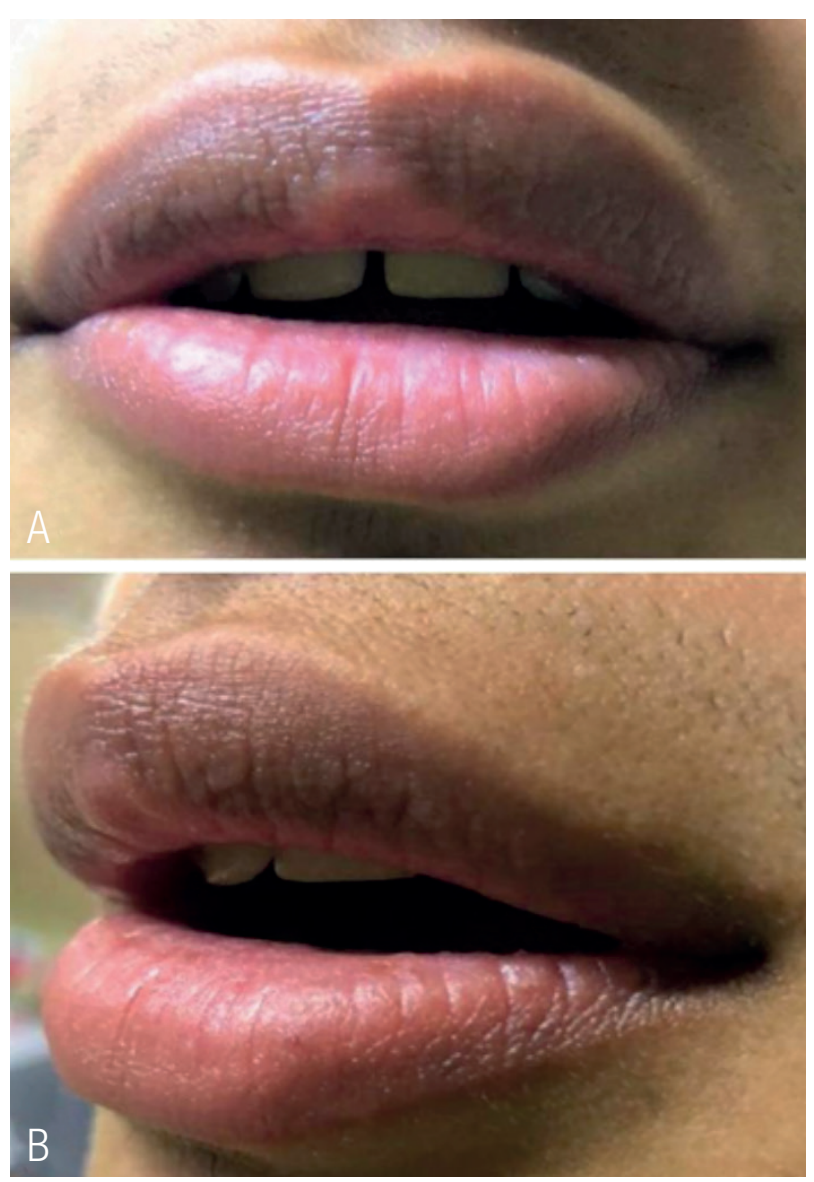

Figure 6. Control after one and a half months, vermilion is observed on both lips moisturized, without the presence of scales and the fissures are less pronounced.

The patients gave their free and informed consent in writing for the publication of their case. 
DISCUSSION

The present case reports clinical characteristics that coincide with the literature, with the difference that it concerns men and EC has been reported predominantly in young women and children (11). It is more common in the vermilion of the lower lip, but it can occur in the upper lip or in both (12) as in our cases. Likewise, these are two patients who have experienced cyclical flaking of the lips despite minimizing the factual sources of irritation (13), such as biting, sucking or pinching the vermilion.

Although the etiology is unknown, actinic damage, cold, wind, and/or nutritional deficiencies (iron and vitamin B12) are believed to play a role in the pathogenesis of EC (7). Likewise, a relationship with stressful situations or psychiatric conditions has been reported, most cases of EC occur when patients are not controlled with medication or therapy (14). In both reported cases, stress and anxiety was an important factor, in which the patients chewed their lips and peeled off the flakes, on several occasions until leaving the bleeding vermilion as in case 2. Behavioral therapy helped them.

The most common clinical manifestations include desquamation in the vermilion of the lips with crusting and erythema (13). This is due to an overproduction of keratin that, when the scales are removed, leave normal lip tissue under them (15), although they may have a hemorrhagic appearance, superficial fibrosis and, in more advanced cases, fissures may appear (5). As in the two reported cases, one being more serious than the other, both referring to pulling off those flaking not only for aesthetics, but because it made them uncomfortable to live a normal life.
Patients may experience other associated signs and symptoms such as tingling, pain, itching, tenderness and burning sensation on the lips, thus they tend to moisten them with their tongue (15), often, patients do not realize to what extent they lick their lips. Saliva contains digestive enzymes that cause a breakdown of the protective barrier in vermilion, with the consequent reduction in humidity and greater vulnerability to irritants $(3,16)$. This combination leaves lips prone to dryness, cracking, bleeding, and flaking (3). With the breakdown of the protective barrier, the risk of secondary infections also increases, as in case 1 that EC was associated with a candida infection.

Usually, the diagnosis is made by exclusion, it is important to rule out sources of allergic or irritant dermatitis (17), bacterial or candida infection and cheilitis glandularis by biopsy, culture and patch tests (10). In reported case 1, the biopsy was key in treating the superinfection with candida. Likewise, some lip balms, mainly indicated to treat chapped and dry lips, have paradoxically been found to exacerbate EC in certain patients $(2,5)$, therefore, a complete medical history is of utmost importance, where the Previous treatments used, their effectiveness or adverse effect, an example of this, is case 1 , which had already used different options, from topical to systemic to treat their EC without success or even aggravating the condition.

A correlation between vermilion hydration and the severity of its desquamation has been reported (18), since it has unique characteristics because it is found on the border of the mucous membrane and facial skin (19). Unlike the skin of the rest of the body, it comprises a thin stratum corneum, has no hair or sweat glands, has a greater transepidermal water loss and a lower water content than the skin of the cheeks (20). For this reason, 
it is more susceptible to dry conditions and hydration of the patient is of the utmost importance, as in the two reported cases, both patients consumed little or no water, and in case 2 dryness was also evident in the perioral skin.

Treatment of EC is difficult due to its chronic nature (9). Topical treatments that have been reported with variable response rates include corticosteroids, antibacterial and antifungal ointments, sunscreen, herbal products, petroleum jelly, 20\% urea ointment, $2 \%$ to $3 \%$ salicylic acid ointment, tacrolimus $0.1 \%$ ointment and cryotherapy with liquid nitrogen (19). However, it is difficult to determine whether patients respond due to the effect of the topical medication itself or because the moisturizing agents act as emollients, preventing patients' lips from drying out (15). Vitamin E has anti-inflammatory, antioxidant and photoprotective properties, its application reduces problems such as dryness and premature deterioration of the skin (21). In case 1, the topical application of vitamin E favored the clinical appearance of vermilion.

Systemic treatments such as antidepressants, antifungals, and corticosteroids have had variable efficacy (7). However, it is not clear the efficacy associated with the antidepressant or if the improvement was due to the modification of parafunctional habits (14). As in the two reported cases, both patients decreased biting, licking and touching the vermilion with their tongue and fingers, substantially improving the clear help with hydration, the use of lip balm and behavioral therapy.

This case report is relevant since it exposes a health problem, which not only affects physically. EC can reduce a patient's quality of life by affecting aesthetics and normal functions such as eating, speaking, and smiling $(8,14)$. The lips are of great importance for the perception of beauty by humans, the appearance of the lips partly deter- mines the attractiveness of a person's face (1), which, in patients as young as those reported, means a lot to socialize commonly and to engage in a love relationship.

\section{CONCLUSIONS}

It is important that health personnel, especially dentists, are aware that the clinical manifestations of EC can vary from one patient to another, as well as its treatment.

It is necessary to establish a correct diagnosis, excluding other conditions with the support of a detailed anamnesis and complementary tests. Determine possible factors that favor dryness and superinfection such as biting and licking the lips; as well as anxiety and dehydration problems, it facilitates the clinical management of what should be avoided and corrected; in addition to the benefit of using topical vitamin $E$ and behavioral aid to improve this condition and patient's life quality.

\section{CONFLICTS OF INTEREST}

None declared.

\section{AUTHOR CONTRIBUTION STATEMENT}

Conceptualization and design: Y.B.O., A.M.L.

Literature review: Y.B.O., A.M.L.

Methodology and validation: Y.B.O., A.M.L.

Formal analysis: Y.B.O., A.M.L.

Investigation and data collection: Y.B.O., A.M.L.

Resources: not applicable.

Data analysis and interpretation: Y.B.O., A.M.L. Writing-original draft preparationl: Y.B.O., A.M.L. Writing-review \& editing: Y.B.O., A.M.L.

Supervision: Y.B.O.

Project administration: not applicable.

Funding acquisition: not applicable. 


\section{REFERENCES}

1. Kar M., Muluk N.B., Bafaqeeh S.A., Cingi C. Is it possible to define the ideal lips? Acta Otorhinolaryngol Ital. 2018; 38 (1): 67-72.

2. Greenberg S.A., Schlosser B.J., Mirowski G.W. Diseases of the lips. Clin Dermatol [Internet]. 2017; 35 (5): e1-14. Available from: https:// doi.org/10.1016/j.clindermatol.2017.11.003

3. Fonseca A., Jacob S.E., Sindle A. Art of prevention: Practical interventions in lip-licking dermatitis. Int J Women's Dermatology [Internet]. 2020; 6 (5): 377-80. Available from: https://doi.org/10.1016/j. ijwd.2020.06.001

4. Sánchez-Herrero A., Mateos-Mayo A., Rodríguez-Lomba E., Molina-López I., Campos-Domínguez M., Suárez Fernández R. Allergic contact cheilitis in an adolescent to Ricinus communis seed oil (castor oil) in a lip balm. Contact Dermatitis. 2018; 79 (3): 176-8.

5. Lindenmüller I.H., Itin P.H., Fistarol S.K. Dermatology of the lips: Inflammatory diseases. Quintessence Int (Berl). 2014; 45 (10): 875-83.

6. Boza Oreamuno Y.V., Guillén Colombari D. Queilitis actínica: Reporte de tres casos y revisión de literatura Actinic Cheilitis : Report of Three Cases and Review of Literature. ODOVTOS-Int J Dent Sc. 2018; 3 (20): 33-42.

7. Almazrooa S.A., Woo S. Bin, Mawardi H., Treister N. Characterization and management of exfoliative cheilitis: A single-center experience. Oral Surg Oral Med Oral Pathol Oral Radiol [Internet]. 2013; 116 (6): e485-9. Available from: http://dx.doi.org/10.1016/j. oooo.2013.08.016

8. Seong Park C., Park J.H., Lee J., Jeong Byun H., Lim Y., Hee Lee J., et al. Chronic exfoliative cheilitis successfully treated by pinhole method using $\mathrm{CO} 2$ laser. Ann Dermatol. 2019; 31 (3): 361-3.

9. Girijala R.L., Falkner R., Dalton S.R., Martin B.D. Exfoliative Cheilitis as a Manifestation of Factitial Cheilitis. Cureus. 2018; 10 (5): 1-5.

10. Bhatia B.K., Bahr B.A., Murase J.E. Excimer laser therapy and narrowband ultraviolet $\mathrm{B}$ therapy for exfoliative cheilitis. Int J Women's Dermatology [Internet]. 2015; 1 (2): 95-8. Available from: http://dx.doi.org/10.1016/j. ijwd.2015.01.006

11. Sun K., Liu L., Chen X., Jiang W. Treatment of exfoliative cheilitis with Traditional Chinese Medicine: a systematic review. J Tradit Chinese Med $=$ Chung i tsa chih ying wen pan. 2017; 37 (2): 147-58.

12. Lugović-Mihić L., Pilipović K., Crnarić I., Šitum M., Duvančić T. Differential diagnosis of cheilitis - How to classify cheilitis? Acta Clin Croat. 2018; 57 (2): 342-51.

13. López-Torres Hidalgo J., García Atienza E.M., Sáez Moreno M.Á., Castaño Díaz M. Queilitis exfoliativa. REV CLÍN MED FAM 2019; 2019; 12 (1): 21-3.

14. Leyland L., Field E.A. Case report: exfoliative cheilitis managed with antidepressant medication. Dent Update. 2004; 31 (9): 524-6.

15. Thongprasom K. Glycerin borax treatment of exfoliative cheilitis induced by sodium lauryl sulfate: A case report. Acta Stomatol Croat. 2016; 50 (2): 158-61.

16. Peyrot des Gachons C, Breslin PAS. Salivary Amylase: Digestion and Metabolic Syndrome. Curr Diab Rep. 2016; 16 (10): 102.

17. Zhou L.L., Pratt M. Allergic contact cheilitis from a variety of lip balm ingredients. J Cutan Med Surg. 2018; 22 (3): 333-5.

18. Kim J., Yeo H., Kim T., Jeong E. taek, Lim J.M., Park S.G. Relationship between lip skin biophysical and biochemical characteristics with corneocyte unevenness ratio as a new 
parameter to assess the severity of lip scaling. Int J Cosmet Sci. 2021; 43 (3): 275-82.

19. Georgakopoulou E., Loumou P., Grigoraki A., Panagiotopoulos A. Isolated lip dermatitis (atopic cheilitis), successfully treated with topical tacrolimus $0.03 \%$. Med Oral Patol Oral y Cir Bucal. 2021; 26 (3): e357-60.
20. Tagami H. Location-related differences in structure and function of the stratum corneum with special emphasis on those of the facial skin. Int J Cosmet Sci. 2008; 30 (6): 413-34.

21. Lee G.Y., Han S.N. The role of vitamin E in immunity. Nutrients. 2018; 10 (11): 1-18. 